\title{
Hypepreneur: Digital Platform to Accelerate Business Opportunities for Millennials
}

\author{
Madania Agusta $^{1, *}$ Retnaningsih $^{1,}$ Dikky Indrawan $^{1}$ \\ ${ }^{1}$ Sekolah Bisnis IPB University \\ *Email: madaniata@hotmail.com
}

\begin{abstract}
The shift of shopping behavior from offline into online platform grows new startups and SMEs in Indonesia. The increase number of new business put Indonesia in number one ranking among Asia Pacific countries with an entrepreneurial spirit. However, due to lack of experience, startups businesses face many challenges that lead to business failures. This research aimed to identify a digital platform solution in supporting new startups businesses to grow. The digital platform was designed by applying House of Quality methods to select the best features. The method transformed user demands into digital platform design for different types of user such as business seekers, businessmen, consultants, investors, and jobseekers. The results developed 43 demanded features based on consumer expectations. Each type of potential consumer chose 1 priority feature. These 5 priority features were implemented in the digital platform prototype.
\end{abstract}

Keywords: Business opportunities, digital platform, millennials, House of Quality

\section{INTRODUCTION}

Current shopping trends are shifting from offline to online. With digitalization, consumers can shop more flexibly online. This can be seen from the value of ecommerce transactions in Indonesia which increased $151 \%$ from 30.942 trillion rupiah in 2017 to 77.766 trillion rupiah in 2018 (W. Daniel). The average online shopping also increased from 2.2 million rupiah per month per consumer in 2018 to 3.8 million rupiah per month per consumer in 2019 (D. Syarizka).

The rising trend of shopping in Indonesia is driving the growth of startups and new MSMEs. The number of startups in Indonesia increased from 1,706 startups to 2,167 startups in 2018 to 2019 or an increase of $27 \%$. This number puts Indonesia in fifth place with the most startups in the world (Startup Ranking). Similarly, the growth of MSMEs has increased by 13.98\% from 2012 to 2017 and $2.02 \%$ in 2017 to 2018 (Kementerian Koperasi dan UKM). In Bogor alone there were 20 startups in 2018 (MIKTI) and 23,706 MSMEs in 2019 (DISKOMINFOSTANDI Kota Bogor).

The increase in the number of startups and SMEs is in line with the high interest in entrepreneurship among
Indonesians. In Asia Pacific, the most sought after opportunities are entrepreneurship and career advancement with a percentage of $15 \%$ each. In Indonesia, the most sought-after opportunity is entrepreneurship with a percentage of $34 \%$ which places Indonesia as the 1st country with an entrepreneurial spirit in the Asia Pacific (LinkedIn). The most widely bought consumer goods sector online also varies from fashion, travel, books and music, IT and cellphones, and event tickets (Katadata).

Despite the high interest in entrepreneurship in Indonesia, it turns out there are also obstacles that make it difficult for businesses to develop. Only 5\% of startups survive in Indonesia (M. Chua). While SMEs are also considered to be unable to compete and only survive in small businesses according to President Jokowi (B. Farras) and in the range of 2015 to 2018 about 1.7 million MSMEs are closed (Mentari.news). There are 20 causes of business failure in building their business, including products not needed in the market (42\%), too much 'burning money' (29\%), team not solid (23\%), losing in competition (19\%), and pricing / cost issues (18\%) (CB Insights). Meanwhile according to 
Kemenkop and UKM, MSMEs should fix the basic problem first, namely financial management.

Based on this problem, researchers want to help prospective entrepreneurs have other perspectives on their efforts to be more competitive in starting a business. Researchers see the company TechHub and Studentprenenur as one of the inspirations in accelerating business opportunities. Both are entrepreneur communities, but use different media. The TechHub company is in the form of coworking space, while Studentpreneur is in the form of a website.

Researchers want to create a digital-based personal service that is a digital platform that provides a variety of solutions integrated in one container. Digital platforms can provide experiences of convenience, speed of information and reciprocal responses, and are effective in conveying accurate information. Differentiation from this digital platform is a combination of several integrated solutions, namely a digital community that brings together prospective entrepreneurs to share ideas and build networks, business consulting, and business strategy content to help prospective entrepreneurs in starting a business. The target is specific to millennial generation so that the price of services offered is relatively affordable.

In creating a digital platform, effective or not depends on the features provided by this digital platform. Not just creating the perfect product, but the main one is correctly answering the problems of prospective entrepreneurs. There are several methods that have been used in developing digital platforms. With so many ideas that can help entrepreneurs in seeing business opportunities, we need tools that can cone the best features that suit the needs and desires of prospective entrepreneurs. With the House of Quality method, the needs and desires of consumers can be changed into service attributes that will be developed. The attributes are even sorted according to priority based on the needs of prospective entrepreneurs in the form of features implemented on this digital platform prototype.

\section{MATERIALS AND METHODS}

\subsection{Sampling Technique}

Data is collected in Bogor from from February until March 2020. This research uses probability sampling technique by determining the sample using cluster sampling. Sampling is done by taking the same number of samples in each cluster. The cluster is divided into five parts in the millennial generation aged 19 years to 39 years in the City of Bogor, namely (1) as a business seeker; (2) as a businessman; (3) business consultant; (4) investors; and (5) jobseeker.

The population of people aged 19 years to 39 years in Bogor City is 373,621 people (BPS Kota Bogor). The number of people aged 19 years to 39 years in Bogor City who have an interest is assumed to be $34 \%$ of the population aged 19 years to 39 years in Bogor City (referring to the percentage of entrepreneurs as the most sought after opportunities in Indonesia according to LinkedIn), namely 127,031. The minimum sample size calculation technique uses the Slovin Formula.

$$
\mathrm{n}=\mathrm{N} /\left(1+\left(\mathrm{N} \mathrm{x} \mathrm{e}^{2}\right)\right.
$$

$\mathrm{n}$ : number of samples

$\mathrm{N}$ : total population

e: error margin

$\mathrm{n}=127,031 /(1+(127,031 \times(0,1) 2)$

$\mathrm{n}=127,031 / 1,271.31$

$\mathrm{n}=99.921341 \approx 100$ samples.

\subsection{The Stages of Prototype Development}

The first stage is benchmarking to determine the performance of similar companies. Second, developing prototype with features from the benchmarking performance analysis. Third, House of Quality to get features based on needs and desired of consumers Forth, Contingent Valuation Method to determine willingness to pay (WTP) for services in digital platform by averaging the value of WTP. Last, developing the second prototype of digital platform.

\subsection{Data Collecting Techniques}

The data collected consists of primary data and secondary data. Primary data is the problems in starting a business, the needs and desires of business seeker, and willingness to pay obtained from survey. Secondary data is a data of benchmark company and technical of digital platforms. 


\section{RESULTS}

\subsection{Business Problems}

Business seeker are faced with various challenges in starting a business. Some of them lead to business failure. For business seeker who are just starting a business, especially small businesses, the resources are still limited so that it leads to the problem factor, namely the difficulty of finding trusted partners and high production costs. It is important for business seeker to set goals, in this case is not able to determine the target market. Another problem is licensing of MSMEs. Consultation is also a problem where $52 \%$ of respondents complained about costs and 32\% did not know access to business consultants. While looking for capital is also a problem but does not have too much influence.

In the period of business development, businessman are also faced with various challenges that can lead to business failure. According to employers, the first problem is finding quality workers as the characteristics of MSMEs, labor intensive. The next problem is poor marketing. Businessman did not consult with experts where $32 \%$ of respondents did not know access to business consultants and $23 \%$ complained about costs. The next problem is the problem of financial management and bad business models. Losing the competition, the team is not solid, and licensing is also a problem for businessman but does not have too much influence. According to consultant, the problem in entrepreneurship are lack of purpose, marketing, organizational culture, unfair competition, capital, and regulation.

\subsection{Benchmarking}

The first benchmark company is TechHub. TechHub is a coworking space for millennials in UK, US, and India. TechHub deliver technology business in various industries with $£ 600$ per year per person - $£ 1800$ per month per team to rent a coworking space. The second benchmark company is Studentpreneur, a startup from Surabaya which provide blogs and learning videos in website about entrepreneurship. The target of Studentpreneur is teenagers to develop businesses in various industries with $\mathrm{Rp} 0$ - Rp 4,500,000 per learning video. Meanwhile, Hypepreneur positions itself as a digital platform with a variety of integrated features, such as gathering business seeker, consulting, and business-related content.

\subsection{The First Prototype of Hypepreneur}

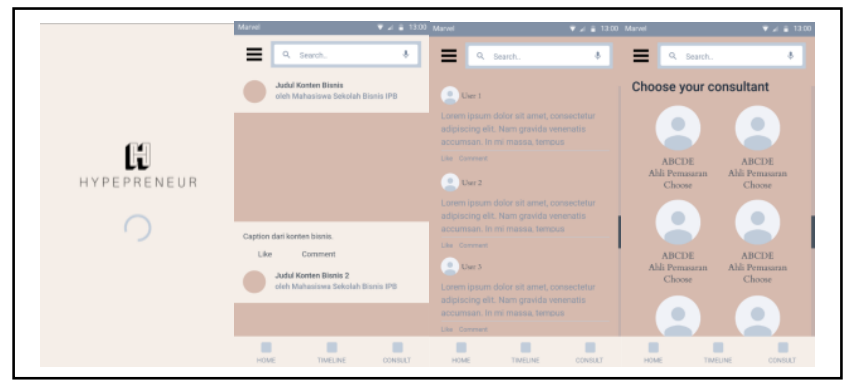

Figure 1 The First Prototype of Hypepreneur

\subsection{House of of Quality}

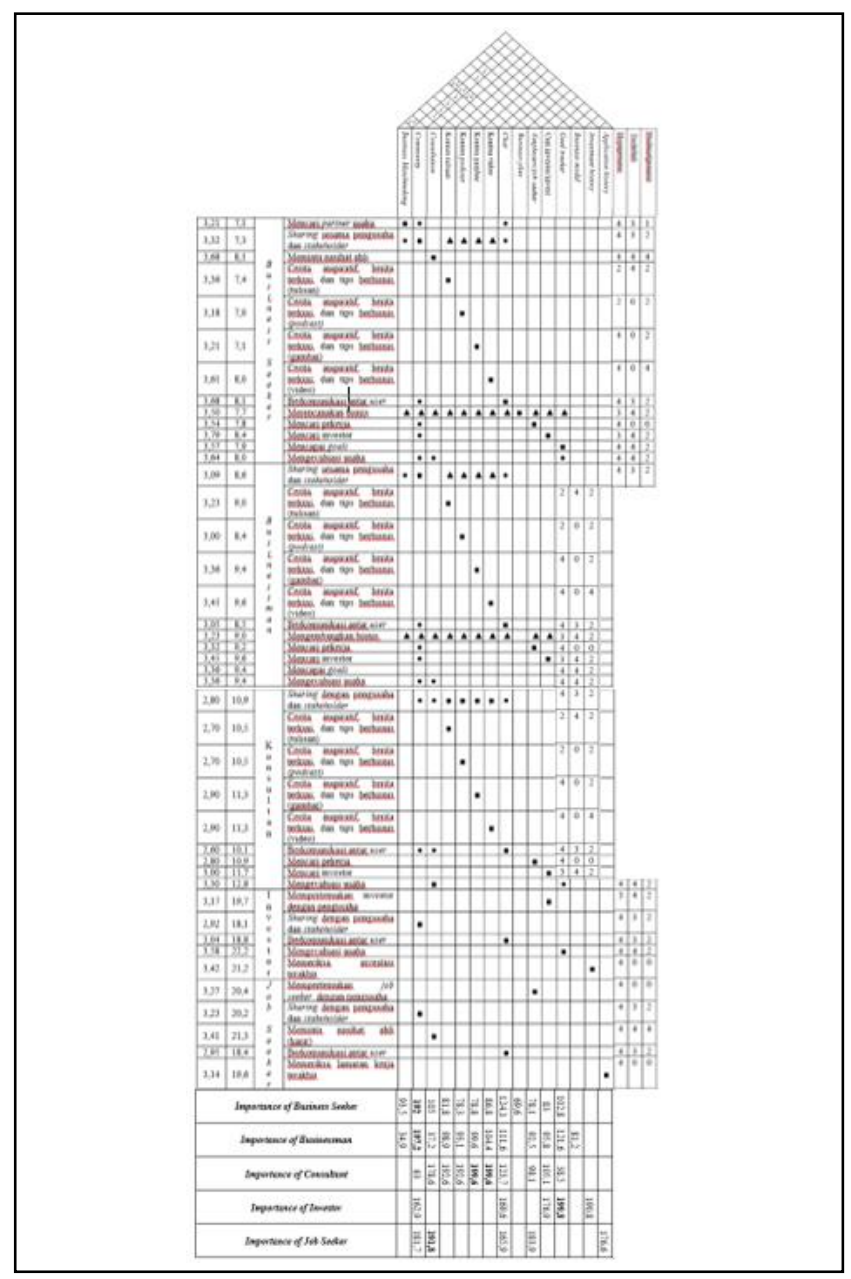

Figure 2 House of Quality of Hypepreneur

House of Quality Hypepreneur as a whole can be seen in Figure 2. The House of Quality design was built by Customer Requirements on the left, Technical Response in the middle along with Relationship Matrix, Technical Correlations on the roof, Target Matrix on the right, and the value of the level of technical importance at the bottom. The conclusion of the House of Quality method can be seen in the value of the level of technical importance which is the accumulation of the multiplication of the weight of consumer interests with 
the weight of technical parameters. The level of technical importance with the highest value is a priority in developing the second prototype of Hypepreneur.

The feature with the highest importance according to business seekers is Community, a digital community that brings entrepreneurs and stakeholders together to explore new ideas, solve problems, and build networks. The feature with the highest importance value according to the businessman is also a Community. Features with the highest importance according to consultants are image content and video content that contains inspirational entrepreneur stories, the latest business news, and tips on doing business.

The feature with the highest importance value according to investors is a goal tracker that can encourage entrepreneurs to achieve goals while evaluating their business by tracking current conditions against targets based on income and profit indicators. The feature with the highest importance according to jobseeker is consultation to find work interest tp know where to apply for works. These five features implemented in the second prototype of Hypepreneur. In addition, Hypepreneur will be designed in blue according to the color most respondents choose by $38 \%$ compared to other colors.

\subsection{Contingent Valuation Method}

Table 1. Willingness to pay for consultation features

\begin{tabular}{|l|r|r|r|}
\hline No & WTP (RP/hour) & Frequency & WTP x Frequency \\
\hline 1. & 25.000 & 1 & 25.000 \\
\hline 2. & 30.000 & 1 & 30.000 \\
\hline 3. & 50.000 & 2 & 100.000 \\
\hline 4. & 100.000 & 10 & 1.000 .000 \\
\hline 5. & 125.000 & 1 & 125.000 \\
\hline 6. & 150.000 & 6 & 900.000 \\
\hline 7. & 167.000 & 1 & 167.000 \\
\hline 8. & $\mathbf{2 0 0 . 0 0 0}$ & $\mathbf{1 1}$ & $\mathbf{2 . 2 0 0 . 0 0 0}$ \\
\hline 9. & 250.000 & 5 & 1.250 .000 \\
\hline 10. & 300.000 & 6 & 1.800 .000 \\
\hline 11. & 350.000 & 1 & 350.000 \\
\hline 12. & 400.000 & 1 & 400.000 \\
\hline 13. & 500.000 & 1 & 500.000 \\
\hline 14. & 1.000 .000 & 1 & 1.000 .000 \\
\hline & & $\mathbf{4 8}$ & $\mathbf{2 0 5 . 1 4 6}$ \\
\hline
\end{tabular}

Table 2. Willingness to pay (WTP) for Premium Content

\begin{tabular}{|l|r|c|r|}
\hline No & WTP (RP/hour) & Frequency & WTP x Frequency \\
\hline 1. & 50.000 & 3 & 150.000 \\
\hline 2. & 87.000 & 1 & 87.000 \\
\hline 3. & 100.000 & 8 & 800.000 \\
\hline 4. & 150.000 & 2 & 300.000 \\
\hline 5. & 200.000 & 6 & 1.200 .000 \\
\hline 6. & 235.000 & 1 & 235.000 \\
\hline 7. & 250.000 & 1 & 250.000 \\
\hline $\mathbf{8 .}$ & 300.000 & 5 & 1.500 .000 \\
\hline 9. & 425.000 & 1 & 425.000 \\
\hline 10. & $\mathbf{5 0 0 . 0 0 0}$ & $\mathbf{1 1}$ & $\mathbf{5 . 5 0 0 . 0 0 0}$ \\
\hline 11. & 725.000 & 1 & 725.000 \\
\hline 12. & 1.000 .000 & 4 & 4.000 .000 \\
\hline 13. & 2.500 .000 & 1 & 2.500 .000 \\
\hline 14. & 5.000 .000 & 1 & 5.000 .000 \\
\hline & & $\mathbf{4 6}$ & $\mathbf{4 9 2 . 8 7 0}$ \\
\hline
\end{tabular}

Based on Tabel 1, the average WTP value consulting services is Rp205.146 per hour. Tabel 1 also shows the mode value of Rp. 200,000 per hour. Therefore, the price of consulting services is Rp.200,000 - Rp 205.146 per hour which considered competitive among similar services. Based on Table 2, the average WTP value of premium content is Rp.492.870 per year. Table 2 also shows the mode value of Rp.500.000 per year. Therefore, the price of premium content is Rp.492.000 Rp 500.000 per year.

\subsection{Development of The Second Prototype}

The development of the second prototype is the result of House of Quality ith features selected directly by various types of respondents. The second prototype can be accessed by bit.ly/prototypehypepreneur.

\section{CONCLUSION}

The problem of business seeker in starting a business are high production costs, consultation, not doing market research, licensing, and looking for trusted partners. This is different from the problem of businessman who have been running in developing a business. The problems of businessman are poor marketing, bad business models, financial management, consultation, and looking for qualified workers. While on the other hand, the problem according to business consultant are not having a goal, marketing, organizational culture, unfair competition, capital, and regulation. These three perspectives differ according to their positions in the business, which is to start, implement, and provide advice. 
Based on the problems, the solution is to gathering these business actors in one platform. This platform was built using the House of Quality which utilizes 43 list of requirements for services that developed according to five types of respondents, that is business seekers, businessmen, consultants, investors, and jobseekers. Through the House of Quality method, out of 43 needs and desires of potential customers, five attributes are obtained based on the priority needs and desires of the type of consumer. This platform is named Hypepreneur.

House of Quality provides a prototype design based on important features of business actors. A feature that is considered important by business seekers is community. Features that are considered important by businessmen is also community. Features that are considered important by the consultant are content in the form of images and videos. A feature that is considered important by investors is goal tracker. A feature that is considered important by the jobseeker is consultation. These five features selected directly by business seeker and stakeholders are implemented in a digital platform prototype to help solving the problems of business seeker in starting a business.

\section{REFERENCES}

[1] B. Farras, "UMKM Kalah Saing Jokowi Beberkan Masalahnya," CNBC Indonesia, in internet.

[2] BPS Kota Bogor, "Jumlah Penduduk Menurut Kelompok Umur dan Jenis Kelamin di Kota Bogor," Badan Pusat Statistik Kota Bogor, in internet.

[3] CB Insights, "The Top 20 Reasons Startups Fail," CB Insights, in internet.

[4] D. Syarizka, "Survei SHopback: Rata-Rata Belanja Konsumen di E-Commerce Meningkat," Bisnis.com, in internet.

[5] DISKOMINFOSTANDI Kota Bogor, "Pelatihan House Production Diikuti 75 Pelaku UMKM di Kota Bogor," Dinas Komunikasi, Informatika, Statistik, dan Persandian Kota Bogor in internet.

[6] Katadata, "Produk Fashion Paling Banyak Diburu Konsumen Online," Katadata, in internet.

[7] Kementerian Koperasi dan UKM, "Perkembangan Data Usaha Mikro, Kecil, da Menengah (UMKM) dan Usaha Besar (UB) Tahun 2016-2017,", Kementerin Koperasi dan UKM, in internet.

[8] LinkedIn, "APAC LinkedIn Opportunity Index 2018: Perceptions of Access and Barriers to Opportunity in Asia Pacific," LinkedIn, in internet.

[9] M. Chua, "Rudiantara: Hanya 5\% Startup yang Survive, 95\% Lainnya Gagal," CNBC Indonesia, in internet.

[10] Mentari.news, "1,7 Juta UMKM Bangkrut, Tak Kuat Bersaing di Era 4.0," Mentari.news, in internet.

[11] MIKTI, "Mapping \& Database Startup Indonesia 2018," Masyarakat Industri Kreatif Teknologi Informasi, in internet.
[12] Startup Ranking, "Countries - With the Top Startups Worldwide," Startupranking, in internet.

[13] W. Daniel, "Wow! Transaksi e-Commerce RI 2018 Capai Rp77 T, Lompat 151\%," CNBC Indonesia, in internet. 